\title{
Foreword: childhood and social exclusion - a sociology of the south?
}

\section{Manuel Jacinto Sarmento}

Over the last two decades, in Central and Northern Europe, the sociology of childhood has been developing, placing its main focus of analysis on childhood as a generation in contrast to the adult generation. ${ }^{1}$ It is understandable why this polarity has become a shining principle of this new area of sociology, considering the previous invisibility of childhood and children in the social sciences. However, one of the effects of focusing on intergenerational relations has been the concealment of social differences; the erasure of the effects of class on childhood conceptualization; and the exclusion of issues such as child poverty from mainstream studies in the field. These themes have been confined to subject areas such as social work and social policy. Not long ago, Qvortrup (2009) rejected the 'temptation of diversity' to defend the unitary character of childhood as a sociogenerational category and to sustain the focus of sociological analysis on the processes of social constitution of the structural relation between childhood and other generational categories.

However, the sociology of childhood developed in the countries of Southern Europe always gave priority to class differences in its approach to childhood. Issues such as child labour, child poverty, public policies and discrimination against children of low social status, ill-treatment, migrant, minority and oppressed children, have been central in this sociological work. In Portugal and Brazil, the focus on the poor child is a structuring characteristic of this Lusophone linguistic variant within the discipline (Sirota, 2012). Considering the universalistic scientific focus in sociology of childhood, the combination of social, cultural and epistemological factors creates variations in knowledge production in countries with linguistic specificities. In this sense, it is possible to speak about a 'southern' sociology of childhood, characterized by the particular contribution it makes to the scientific field of childhood studies.

The countries from Southern Europe (in particular, Greece and Portugal), far removed from the per capita income indicators of Central and Northern

$1 \quad$ For a summary presentation of the sociology of childhood, cf. the work of Gaitán Muñoz (2006) and Almeida (2009). 
European countries, have recently experienced a period of economic and financial crisis, with draconian management under the aegis of international regulatory organizations such as the IMF, the European Union and the European Central Bank, which has led to an increase in social inequalities and the impoverishment of the working classes and larger middle-class sectors. The weaknesses of the social state in these countries (with the addition of Spain), which emerged in the 1970s from dictatorships that delayed in three decades the construction of the welfare state, had unique consequences for children's well-being. Children are especially vulnerable, despite the important, but insufficient, democratic progress that has been made in terms of child well-being. This fact has an important impact on the sociological research of childhood, which finds in the social exclusion of childhood, in its conceptualization and, above all, in its conditions of realization, an important topic of analysis.

The detailed empirical analyses of the social conditions of life of children in the countries of Southern Europe constitute a significant amount of the recent sociological work. However, from this empirical work, and in mutual intercommunication with it, it is possible to identify theoretical themes of great importance that cross the sociology of childhood in Southern Europe and are specific contributions to the international construction and sharing of knowledge. These themes are childhood normativity and the plurality of conditions of generativity (Honig, 2009), especially in children of subaltern social groups; the configuration of a paradigmatic orientation based on critical theory, in an international field marked by the predominance of other approaches, namely structuralist, interpretative or deconstructionist; and a public sociology as an important strand of knowledge production and dissemination.

\section{NORMATIVITY}

The difference between generations and their conditions of life is a process widely studied in the sociology of childhood and probably structuring of its theoretical path. The generations are distinguished from each other and their differentiation is constitutive of each of them. They are socially constructed from the conception of social norms that establish their relations and guarantee what is acceptable, admissible and adequate, or, conversely, what is illegitimate, prohibited or considered improper. For example, in modern Western and European societies, it is considered inappropriate for younger generations to have a regular productive activity and, on the other hand, the 'right to work' of the adult population is considered a social norm (despite the relatively high unemployment in Western capitalist countries).

The mutual production of generations (generativity) is deeply normative. And from this focus we define what it is to be a child and what is not. The very 
concept of 'childhood' is sometimes used not in the analytical sense of a generational category of its own, but as a purely normative concept. It happens when it is used in the current expression of 'children without childhood', that is to say, deprived of the characteristics that are normatively associated with children: protection, school attendance, family membership, minimum conditions of comfort, access and right to play activities, and so on. In our opinion, this is the central point in which the debate about the plurality of child normativity makes sense (Sarmento, Marchi and Trevisan, 2018).

The special vulnerability of poor children places many of them away from their families (street children and foster children), leaving school early, and not protected by state policies. In fact, they are outside the Western and Eurocentric norm that proclaims the notion of the protected child. The research of the social status of the children in a position of subalternity cannot be made without questioning the Western norm of childhood.

The debate about child normativity considers two intersecting paths. The first is the critique of the hegemonic position (including within the theoretical field itself) on the universality of the Western and Eurocentric norm of childhood and its theoretical and political consequences in the blurring of the cultural and social differences of children in subalternity or on the periphery. This line of discussion seeks to identify the complex relationships between generational identity and cultural difference, to rescue invisible children from invisibility, to foster a critical reading of the Convention on the Rights of the Child and international agencies of childhood (Gaitán Muñoz, 2018; Sgritta, 1997), aside from the requirement of a political guarantee that addresses the difference in the fight against social inequalities and promoting a cosmopolitical view of childhood (Tomás, 2011).

The second way is to survey the cultural practices of children from peripheral contexts of the hegemony of global culture, mobilizing forms of expression and knowledge of the world of children who, to a large extent, escape the canons of school culture. Research carried out with African or South American children establishes a solid dialogue between the sociology of childhood and post-colonial studies and is associated with a growing international tendency to criticize the reductionism of childhood research from the world (Europe and North America), shaving from the theoretical and methodological issues the challenges posed by the children of the Global South (Liebel, 2012; Punch, 2016). Criticism of hegemonic normativity is one of the most promising tasks underway in the theoretical work of the sociology of childhood in Southern Europe. 


\section{CRITICAL SOCIOLOGY OF CHILDHOOD}

Research on child normativity stems from critical thinking. The question of the social oppression of childhood by paternalist conceptions, along with class, cultural and gender social oppression, are research domains that embody a research orientation articulated with social emancipation projects.

This programme of a critical sociology of childhood develops around seven lines of orientation: (1) analytical priority to excluded/stealth/absent children, children at the social margins; (2) deconstruction of the institutional reflexivity of childhood, where normative conceptions are crystallized, with continuous unveiling of the relations between power and knowledge; (3) placing as a critical target the hegemonic process of globalization and institutional individualism and the way it operates in childhood; (4) historization of the social process of construction of intergenerational relations, in dialogue with historical sociology; (5) adoption of a perspective that crosses structure and action, following the social and cultural worlds of childhood and its social practices; (6) openness to the cross-cultural study of socialization processes and refusal of any cultural, social or generational ethnocentrism; and (7) adoption of an ethical and political perspective of the research (Sarmento and Marchi, 2008).

The critical perspective is often expressed in research methodologies oriented towards transformative social participation. The articulation between action research, ethnography and participatory methodologies defines a line of critical interpretivism that is coherent with the dialectical articulation between the plan of action and social structure.

\section{PUBLIC SOCIOLOGY OF CHILDHOOD}

The participation of the sociology of childhood in the evaluation and definition of public policies of childhood is present in the countries of Southern Europe. Even though the sociology of childhood does not claim to be a public sociology (Burawoy, 2005), its importance and participation in the definition of public policies is unquestioned. The influence of the theoretical framework from the sociology of childhood in the assessment and definition of childhood public policies far exceeds, due to its social importance, the notoriety that the discipline has within the academic community of social and human sciences. Thus, several domains of public policies have been studied by sociologists of childhood, who are often invited to carry out evaluation work by governmental bodies or by social institutions that have great relevance and influence in these public policies (notably in Spain and Portugal).

The public sociology of childhood is also reflected in the multiple opportunities to follow local projects to prevent child-risk in child-friendly cities, to 
train educational and social service professionals in the scientific supervision of residential institutions, in the development of municipal policies to promote children's citizenship and in programmes to fight child poverty, and so on.

The public pattern is a striking feature of the sociology of childhood in the countries of Southern Europe, while raising questions about the ethical and emic levels of the production of knowledge and the meanings of scientific work in the production of a reflexive modernity (Beck, Giddens and Lash, 1997), open to critical and plural dimensions of analysis, capable of rescuing childhood in the plurality of its condition, prejudice, paternalism and oppression.

\section{CONCLUSION}

If the research on the lifestyles of Southern European children is a political and social necessity, it also presents itself as an opportunity for theoretical development of the sociology of childhood. Issues such as the normatization, critical orientation and the public character of sociology are determinants perhaps, among others, of this development. It is not a minor contribution to the field of social studies of childhood if it decisively incorporates the social inequalities and their consequences in childhood as a fundamental axis of construction of a sociology open to the intersectionality between generation and social class. Perhaps this will be the major contribution of a 'southern' sociology of childhood.

\section{REFERENCES}

Almeida, Ana Nunes de (2009), Para uma sociologia da infância [Towards a Sociology of Childhood], Lisbon: ICS.

Beck, U., A. Giddens and S. Lash (1997), Reflexive Modernization: Politics Tradition and Aesthetics in the Modern Social Order, Cambridge, UK: Polity Press.

Burawoy, M. (2005), 'For public sociology', American Sociologist, 70(1), 4-28.

Gaitán Muñoz, L. (2006), Sociología de la infancia [Sociology of Childhood], Madrid: Síntesis.

Gaitán Muñoz, L. (2018), 'Los derechos humanos de los niños: ciudadanía más allá de las "3Ps"' [The human rights of children: citizenship beyond the '3Ps'], Sociedad e Infancias, 2, 17-37.

Honig, M.-S. (2009), 'How is the child constituted in childhood studies?', in J. Qvortrup, W.A. Corsaro and M.-S. Honig (eds), The Palgrave Handbook of Childhood Studies, Basingstoke: Palgrave Macmillan, pp. 62-77.

Liebel, M. (2012), Children's Rights from Below: Cross-Cultural Perspectives, Basingstoke: Palgrave Macmillan.

Punch, S. (2016), 'Cross-world and cross-disciplinary dialogue: a more integrated, global approach to childhood studies', Global Studies of Childhood, 6(3), 352-64.

Qvortrup, J. (2009), 'The development in childhood: change and continuity in generational relations', in J. Qvortrup (ed.), Structural, Historical and Comparative 
Perspective: Social Studies on Children and Youth, Vol. 12, Bingley, UK: Emerald, pp. 1-26.

Sarmento, M.J. and R. Marchi (2008), 'Radicalização da infância na segunda modernidade: para uma sociologia da infância crítica' [Radicalization of childhood in the second modernity: towards a critical sociology of childhood], Configurações, 4, 91-113.

Sarmento, M.J., R. Marchi and G. Trevisan (2018), 'Beyond the modern "norm" of childhood: children at the margins as a challenge for the sociology of childhood', in C. Baraldi and T. Cockburn (eds), Theorizing Childhood: Citizenship, Rights and Participation, London: Palgrave Macmillan, pp. 135-57.

Sgritta, G.B. (1997), 'Inconsistencies: childhood on the economic and political agenda', Childhood, 4(4), 375-404.

Sirota, R. (2012), 'L'enfance au regard des sciences sociales' [Childhood in the social sciences], AnthropoChildren, 1, 1-20.

Tomás, C. (2011), 'Há muitos mundos no mundo': cosmopolitismo, participação e direitos da criança ['There Are Many Worlds in the World': Cosmopolitanism, Participation and Children's Rights], Porto: Afrontamento. 